\title{
Social Media as a Vehicle for Conspiracy Beliefs about COVID-19
}

\author{
Andreas Goreis ${ }^{1,2} \&$ Oswald D. Kothgassner ${ }^{3 *}$ \\ ${ }^{1}$ Department of Clinical and Health Psychology, University of Vienna \\ 2 Outpatient Unit for Research, Teaching and Practice, Faculty of Psychology, University of Vienna, \\ Vienna, Austria \\ ${ }^{3}$ Department of Child and Adolescent Psychiatry, Medical University of Vienna
}

\author{
Highlights \\ Conspiracy beliefs are spread via social media platforms and may have a negative impact on preventive health \\ measures. \\ Preventive measures against fear and misinformation need to consider the differential effects of different forms \\ of conspiracy theories on behavior. \\ Fostering awareness in society about COVID-19 misinformation in social media is crucial. \\ Keywords: conspiracy theory, social networking sites, pandemic, COVID-19
}

\author{
Letter History \\ Received 28 June 2020 \\ Revised 28 August 2020 \\ Accepted 28 August 2020
}

DOI 10.24989/dp.v1i2.1866
The SARS-CoV2 virus has caused a global pandemic and health crisis with millions of people suffering from Coronavirus Disease 2019 (COVID-19). The symptoms of the disease include fever, dry cough, dyspnea, and loss of taste and smell, and are similar to those caused by severe acute respiratory syndrome (SARS) and the Middle East respiratory syndrome (MERS), both of which are caused by a coronavirus (Shi et al., 2020, Xydakis et al., 2020). However, the 2020 COVID-19 outbreak represents a massive global health crisis, and conspiracy beliefs relating to the origins and spread of the virus began to manifest themselves in the earliest stages of the pandemic. This is not especially surprising, since in times of acute crisis people tend to attribute significant events to a single, primary cause (Leman \& Cinnirella, 2007; van Prooijen \& Douglas, 2017). Misinformation and conspiracy theories are spread, proliferated, and amplified over social media platforms - most prominently Twitter and Facebook (Frenkel et al., 2020).

Conspiracy beliefs are usually defined as beliefs in the existence of a secret network of multiple actors who join together and try to achieve a hidden goal that is perceived as unlawful or malevolent (Bale 2007; van Prooijen \& Acker, 2015). In other words: someone is pulling the strings. In times of uncertainty and during ubiquitous events, such as the COVID-19 outbreak, some people are drawn to conspiracy theories about the cause or even motivation behind the spread of the virus. The outbreak of the bubonic plague in the $14^{\text {th }}$ century, for example, led to beliefs that Jewish people caused the epidemic and were actively spread- ing the disease through poisoning wells. Other conspiracy theories include the belief that HIV was disseminated to kill Black people, and that the Zika virus was developed as a biological weapon (Geissler \& Sprinkle, 2013, Klofstad et al., 2019). More recently, the Ebola outbreak in West Africa - which lasted from 2013 to 2016 - was accompanied by misinformation conspiracy beliefs (Allgaier, \& Svalastog, 2015). Similar conspiracy beliefs with analogous themes are now emerging during the COVID-19 crisis. There is a wide range of theories and beliefs about the outbreak and its development into a pandemic. An unsystematic review of Facebook content, YouTube channels, and videos from blogs about "COVID-19" reveals a wide spectrum of information about conspiracy beliefs relating to the disease, including the proposition that the pandemic is a governmental conspiracy, and the idea that COVID-19 is all a hoax.

Another observation during the COVID-19 crisis was people defining themselves as experts who interact via social media channels or webpages to inform the community about the actual threat of coronavirus, or the threat of measures against the coronavirus. There are also blogs and YouTube videos of physicians reporting anecdotal evidence from their clinical practice, with some arguing that COVID-19 provokes symptoms no more serious than those of a mild flu, and thus is not a clear and present danger to global health. For observers prone to conspiracy beliefs of this type, this messaging may result in confirmation bias people being drawn to interpretations of evidence which are related to or support an existing hypothesis, belief, or expecta- 
tion - thus further fostering these beliefs (Douglas \& Sutton, 2008). Another explanation could be incorrect interpretations of causality, which means that simple relations are interpreted in a concrete direction.

\section{Who is prone to fall for conspiracy theories?}

Aside from logical fallacies and analytic thinking styles, studies have found socio-political factors to have reliable associations with conspiracy beliefs. Marginalized people and those with authoritarian and right-wing views have been shown to be more attracted to these theories (for a review, see Goreis \& Voracek, 2019). The general paradigm in this regard, however, seems to be one of transition. Due to the ubiquitous availability and virality of conspiracy beliefs, as well as a rise in the distrust of institutions, they appear to be increasingly crossing over into the mainstream (Freeman et al., 2020). Uncertainty during impactful and threatening events - such as a global pandemic - may heighten personal distress. Conspiracy theories are a sense-making devices that provide comprehensive and causal explanations for events, potentially easing distress. Further, some of the conspiracy beliefs can be trademarked by the Dunning-Kruger-Effect, a bias that refers to the erroneous tendency in the self-image of people to overestimate their knowledge and skills (Motta et al., 2018).

\section{Different types of conspiracy theories about COVID-19}

As noted by a recent study (Imhoff \& Lamberty, 2020), conspiracy beliefs about COVID-19 have direct implications for human behavior. Misinformation additionally causes confusion and spreads fear, which may further obstruct the response to the pandemic (Depoux et al., 2020). The director of the WHO called this the fight against "trolls and conspiracy theories", in addition to battling COVID-19 itself. Further, different believes lead to different behaviors. The belief that COVID-19 is a hoax may lead to a decreased perception of threats and danger, while increased risk-taking behavior, in turn, contradicts prevention purposes against the virus. Furthermore, the belief that COVID-19 is a man-made bioweapon will lead to more prepping (i.e. actively preparing for emergencies) and self-centric behavior.

Popular claims are that the pandemic is caused and/or spread by electromagnetic waves via telephone masts (see Kouzy et al., 2020). Using social network analysis, an investigation of Twitter posts showed that the $5 \mathrm{G}$ conspiracy was posted only by isolated groups and a few individual users, with some accounts being set up for the sole purpose of spreading this theory (Ahmed et al., 2020). This study also noted that only a third of the users posting on this topic at the time expressed endorsement and belief in the theory, while the remainder mocked it or shared posts humorously, inadvertently drawing more attention to the topic. Importantly, users may also be presented with this kind of (and adjacent) content due to filter bubbles, the combination of personal preferences and learning algorithms that display content in the news feed of social media (Mortimer, 2017). Users of social media may, therefore, be exposed to information that aligns with their pre-established beliefs, fostering an echo chamber (Messing \& Westwood, 2014). Another recent study found that four main conspiracy narratives were being disseminated during COVID-19:

- the virus being related to $5 \mathrm{G}$ networks, which explains Chinese provenance and assumes a link with the Chinese technology company Huawei, which develops equipment for the networks;

- the release of the virus as a bioweapon;

- the virus being a hoax or no more dangerous than the mild flu;

- the virus being connected to Bill Gates, and a plan to develop a global surveillance system (Shahsavari et al., 2020).

Social media seems to be a strong carrier for conspiracy beliefs, as, people who have conspiracy beliefs are more likely to get their knowledge from social media (Allington et al., 2020).

\section{Impact of COVID-19 conspiracy theories on mental health and health behavior}

Inherent in conspiracy beliefs is a negative association pertaining to compliance with health-protective behaviors as indicated in earlier research about conspiracy theories on vaccines, HIV, and birth control (Thorburn \& Bogart, 2005; Dunn et al., 2017; Grebe \& Nattrass, 2012). In many countries, governmentmandated social-distancing measures were implemented as a response to the pandemic. As long as no pharmacological interventions are available, social distancing and quarantine are the only means feasible to combat the pandemic. Indeed, a first large-scale evaluation of the implementations in six countries confirms their feasibility and efficacy (Hsiang et al., 2020). Some conspiracy theories, however, target prevention and treatment of COVID-19, suggesting that there is no need for decreasing physical contact with others, wearing masks in public hospitals, and general services such as vaccines, or drugs. This spread of conspiracy theories led to a rise of misinformation and unverifiable content (Kouzy et al., 2020). First investigations confirm that endorsement of such theories reduces compliance with mandated measures (Marinthe et al., 2020; Swami \& Barron, 2020). People who believe that COVID-19 symptoms seem to be connected to $5 \mathrm{G}$ radiation in particular are less compliant with guidelines on virus control measures, e.g. social distancing, washing your hands more often etc. This indicates that conspiracy beliefs spread via social media undermine guidelines designed to protect public health. 
First interventions and programs are implemented in an attempt to counter this development, those reach from simple accuracy reminders and subtle nudges to positive impact games and psychological inoculation (e.g. games that help to increase the ability to detect fake news) and visualized video experiments (e.g. videos that show that the prolonged use of medical masks does not lead to oxygen deficiency) (e.g. Pennycook et al., 2020; Roozenbeek \& van der Linden, 2019, van Bavel et al., 2020). Striving to counter the above-mentioned cognitive and statistical biases, and increase analytic thinking, such programs utilize similar strategies that have proven viable to address fake news (Lazer et al., 2018).

\section{Conclusions and Recommendations}

In conclusion, conspiracy beliefs can be easily spread via social media platforms and people who have conspiracy beliefs are more likely to get information from social media - the latter is crucial knowledge as to break this vicious circle of misinformation. Recent studies provide indications that believing in conspiracy theories has a negative impact on preventive health measures. Both future research and public health prevention policy should consider that different specific conspiracy beliefs may lead to different consequences (e.g. in behavior, compliance, or health consequences) in relation to controlling the spread of a pandemic virus. Preventive measures should, therefore, consider these differences and be tailored towards them. This may, however, prove strenuous as echo chambers in online spaces, and the algorithms by used social media companies, produce an environment which can inculcate certain belief systems among social media users. Social media companies are called upon to revise their presentation of news feeds and cooperate with researchers as well as authorities to incorporate scientific evidence gathered during the current crisis into their procedures. A consequential (and thoroughly funded) strategy needs to be implemented to fight the viral spread of misinformation and conspiracies in social media (c.f. Garrett, 2020). Public health campaigns on social media implementing referenced information and providing psychological inoculation might offer useful tools to fight misinformation. Therefore, it is important to strengthen awareness regarding fake news and conspiracy beliefs about COVID-19 in society, and curtail the spread of misinformation to reduce uncertainty in public.

\section{References}

Ahmed, W., Vidal-Alaball, J., Downing, J., \& Seguí, F. L. (2020). Dangerous messages or satire? Analysing the conspiracy theory linking $5 \mathrm{~g}$ to covid-19 through social network analysis. Journal of Medical Internet Research, 22:e19458. https://doi.org/10.2196/19458

Allgaier, J., \& Svalastog, A. L. (2015). The communication aspects of the Ebola virus disease outbreak in Western Africa - do we need to counter one, two, or many epidemics? Croatian Medical Journal, 56, 496-499. https://doi.org/10.3325/cmj.2015.56.496

Allington D., Duffy B., Wessely S., Dhavan N., Rubin J. (2020). Healthprotective behaviour, social media usage and conspiracy belief during the COVID-19 public health emergency. Psychological Medicine, 1-7. https://doi.org/10.1017/S003329172000224X

Bale, J. M. (2007). Political paranoia v. political realism: On distinguishing between bogus conspiracy theories and genuine conspiratorial politics. Patterns of Prejudice, 41, 45-60. https://doi.org/ 10.1080/00313220601118751

Franks, B., Bangerter, A., \& Bauer, M. W. (2013). Conspiracy theories as quasi-religious mentality: An integrated account from cognitive science, social representations theory, and frame theory. Frontiers in Psychology, 4, 1-12. https://doi.org/10.3389/fpsyg.2013.00424

Depoux, A., Martin, S., Karafillakis, E., Preet, R., Wilder-Smith, A., \& Larson, H. (2020). The pandemic of social media panic travels faster than the COVID-19 outbreak. Journal of Travel Medicine, 27:taaa031. https://doi.org/10.1093/jtm/taaa031

Douglas, K. M., \& Sutton, R. M. (2008). The hidden impact of conspiracy theories: Perceived andactual influence of theories surrounding the death of Princess Diana. The Journal of Social Psychology, 148, 210-222. https://doi.org/10.3200/SOCP.148.2.210-222

Dunn, A.G., Surian, D., Leask, J., Dey, A., Mandl, KD., and Coiera, E. 2017. Mapping information exposure on social media to explain differences in HPV vaccine coverage in the United States. Vaccine, 35, 3033-3040. https://doi.org/10.1016/j.vaccine.2017.04.060

Freeman, D., Waite, F., Rosebrock, L., Petit, A., Causier, C., East, A., ... \& Bold, E. (2020). Coronavirus conspiracy beliefs, mistrust, and compliance with government guidelines in England. Psychological Medicine, 1-30. https://doi.org/10.1017/S0033291720001890

Frenkel, S., Alba, D., \& Zhong, R. (2020, March 8). Surge of Virus Misinformation Stumps Facebook and Twitter. The New York Times. Retrieved from https://www.nytimes.com/2020/03/08/technology/ coronavirus-misinformation-social-media.htm

Garrett, L. (2020). COVID-19: the medium is the message. The Lancet, 395, 942-943. https://doi.org/10.1016/S0140-6736(20)30600-0

Geissler, E., \& Sprinkle, R. H. (2013). Disinformation squared: Was the HIV-from-Fort-Detrick myth a Stasi success? Politics and the Life Sciences, 2-99.

Grebe, E. \& Nattrass, N. (2012). AIDS conspiracy beliefs and unsafe sex in Cape Town. AIDS and Behavior, 16: 761-773. https://doi. org/10.1007/s10461-011-9958-2

Goreis, A., \& Voracek, M. (2019). A systematic review and meta-analysis of psychological research on conspiracy beliefs: Field characteristics, measurement instruments, and associations with personality traits. Frontiers in Psychology, 10:205. http://doi.org/10.3389/ fpsyg.2019.00205

Imhoff, R., \& Lamberty, P. (2020). A bioweapon or a hoax? The link between distinct conspiracy beliefs about the Coronavirus disease (COVID-19) outbreak and pandemic behavior. https://doi. org/10.31234/osf.io/ye3ma

Hofstadter, R. (1966). The paranoid style in American politics. In R. Hofstadter (Ed.), The paranoid style in American politics and other essays (pp. 3-40). New York, NY: Knopf.

Hsiang, S., Allen, D., Annan-Phan, S., Bell, K., Bolliger, I., Chong, T., ... \& Lau, P. (2020). The effect of large-scale anti-contagion policies on the COVID-19 pandemic. Nature, 1-9. https://doi.org/10.1038/ s41586-020-2404-8 
Kouzy, R., Abi Jaoude, J., Kraitem, A., El Alam, M. B., Karam, B., Adib, E., Zarka, J., Traboulsi, C., Akl, A. W., \& Baddour, K. (2020). Coronavirus goes viral: Quantifying the COVID-19 misinformation epidemic on Twitter. Cureus, 12, e7255. https://doi.org/10.7759/ cureus.7255

Klofstad, C. A., Uscinski, J. E., Connolly, J. M., \& West, J. P. (2019). What drives people to believe in Zika conspiracy theories? Palgrave Communications, 5:36. https://doi.org/10.1057/s41599-019-0243-8

Lazer, D. M., Baum, M. A., Benkler, Y., Berinsky, A. J., Greenhill, K. M., Menczer, F., ... \& Schudson, M. (2018). The science of fake news. Science, 359, 1094-1096. https://doi.org/10.1126/science.aao2998

Leman, P. J., \& Cinnirella, M. (2007). A major event has a major cause: Evidence for the role of heuristics in reasoning about conspiracy theories. Social Psychological Review, 9(2), 18-28.

Marinthe, G., Brown, G., Delouvée, S., \& Jolley, D. (2020). Looking out for myself: Exploring the relationship between conspiracy mentality, perceived personal risk and COVID-19 prevention measures. https://doi.org/10.31234/osf.io/cm9st

Messing, S., \& Westwood, S. J. (2014). Selective exposure in the age of social media: Endorsements trump partisan source affiliation when selecting news online. Communication Research, 41, 1042-1063. https://doi.org/10.1177\%2F0093650212466406

Mortimer, K. (2017) Understanding Conspiracy Online: Social Media and the Spread of Suspicious Thinking. Dalhousie Journal of Interdisciplinary Management, 13(1): 1-16. Retrieved from https://ojs. library.dal.ca/djim/article/view/6928

Motta, M., Callaghan, T., \& Sylvester, S. (2018). Knowing less but presuming more: Dunning-Kruger effects and the endorsement of antivaccine policy attitudes. Social Science \& Medicine, 211, 274-281. https://doi.org/10.1016/j.socscimed.2018.06.032

Pennycook, G., McPhetres, J., Zhang, Y., \& Rand, D. (2020). Fighting COVID-19 misinformation on social media: Experimental evidence for a scalable accuracy nudge intervention. https://doi.org/10.31234/ osf.io/uhbk9

Roozenbeek, J., \& van der Linden, S. (2019). Fake news game confers psychological resistance against online misinformation. Palgrave Communications, 5(1), 1-10. https://doi.org/10.1057/s41599-0190279-9

Shahsavari, S., Holur, P., Tangherlini, T. R., \& Roychowdhury, V. (2020). Conspiracy in the time of corona: Automatic detection of covid-19 conspiracy theories in social media and the news. Retrieved from https://arxiv.org/abs/2004.13783

Shi, H., Han, X., Jiang, N., Cao, Y., Alwalid, O., Gu, J., ... \& Zheng, C. (2020). Radiological findings from 81 patients with COVID-19 pneumonia in Wuhan, China: a descriptive study. The Lancet Infectious Diseases. https://doi.org/10.1016/S1473-3099(20)30086-4
Swami, V., \& Barron, D. (2020). Analytic thinking, rejection of coronavirus (COVID-19) conspiracy theories, and compliance with mandated social-distancing: Direct and indirect relationships in a nationally representative sample of adults in the United Kingdom. https://doi.org/10.31219/osf.io/nmx9w

Thorburn, S. and Bogart, L. M. 2005. Conspiracy beliefs about birth control: barriers to pregnancy prevention among African Americans of reproductive age. Health Education \& Behavior 32: 474-487. https://doi.org/10.1177\%2F1090198105276220

Van Bavel, J. J., Baicker, K., Boggio, P. S., Capraro, V., Cichocka, A., Cikara, M., ... \& Drury, J. (2020). Using social and behavioural science to support COVID-19 pandemic response. Nature Human Behaviour, 1-12. https://doi.org/10.1038/s41562-020-0884-zvan Prooijen, J. W., \& Acker, M. (2015). The Influence of Control on Belief in Conspiracy Theories: Conceptual and Applied Extensions. Applied Cognitive Psychology, 29, 753-761. https://doi.org/10.1002/acp.3161

Van Prooijen, J. W., \& Douglas, K. M. (2017). Conspiracy theories as part of history: The role of societal crisis situations. Memory Studies, 10(3), 323-333. https://doi.org/10.1177\%2F1750698017701615

Xydakis, M. S., Dehgani-Mobaraki, P., Holbrook, E. H., Geisthoff, U. W., Bauer, C., Hautefort, C., ... \& Hopkins, C. (2020). Smell and taste dysfunction in patients with COVID-19. The Lancet Infectious Diseases. https://doi.org/10.1016/S1473-3099(20)30293-0

\section{* Corresponding author}

Mag. Dr. Oswald D. Kothgassner, Department of Child and Adolescent Psychiatry, Medical University of Vienna, 0140400 32350, oswald. kothgassner@meduniwien.ac.at

\section{Conflict of Interest}

AG and ODK declare no conflict of interest

\section{Funding}

No funding. 